\title{
LACKÓ LÁSZLÓ:
}

\section{A TERÜLETI FEJLÖDÉS EGYSÉGES ÉRTELMEZESE}

\section{A területi fejlődésről általában}

A területi fejlödés tartalmilag felöleli egy ország egészére, különböző részeire, a településekre jellemző változásokat, a természeti erőforrások, a népesség, a termelés, az infrastrukturális hálózatok és ellátó intézmények területi eloszlási és váitozási viszonyait, a közöttük meglevő kapcsolatokat.

Ebböl következóen a területi fejlödés magában foglalja az urbanizáció, a településfejlődés fogalmát is. Ez a felfogás számottevően eltér a hazánkban megszokotttól, nem tükrözi a tudományos és gyakorlati megosztottságot, azt, hogy külön akarjuk vizsgálni, tervezni a területi vagy településfejlődést, és külön-külön beszélünk területfejlesztésröl, településfejlesztésröl. A lényeg - véleményem szerint - a térbeli változás. Az pedig, hogy a természeti, társadalmi és egyéb tényezők szemszögéböl, illetve különbözó nagyságú területi egységek szerint tekintjük a változást, másodlagos jelentőségü.

Ezen egységes felfogás alkalmazása elméleti-tudományos és gyakorlati szem. pontból is világos, és alkalmas arra, hogy a területi fejlödés tényezőit és szintjeit megfelelö keretben értelmezzük.

A területi fejlödés tartalmára vonatkozó nézeteknek van egy olyan csoportja, amely a területi fejlödést a társadalmi-gazdasági szempontokkal azonosítja, a településfejlödést pedig alapvetöen müszaki jellegünek tekinti. Ennek legnagyobb gyengéje, hogy a közbülsö szintekre vonatkozóan nem ad választ, és csak egyes tényezöket emel ki, a többieket elhanyagolja, ami az elemzésben, megértésben és befolyásolásban is alapvetö zavarokhoz vezet.

A másik felfogás szerint a területi fejlödésnek része, mintegy alárendeltje a településfejlödés. Véleményem - mint a fentiekböl kitünt - az, hogy a területi fejlödést különböző szinteken, de mindig komplexen (valamennyi tényezö figyelembe vételével) kell értelmezni.

A területi fejlödés elméleti és gyakorlati kérdéseit tárgyaló, marxista gazdasági geográfusok általános kiinduló tétele az, hogy a területi fejlödés nem választható el az általános gazdasági fejlödéstöl. (İgy foglalt állást például MARKOS GY. 1956, KÖSZEGI L. 1964, KÓRÓDI I. 1968, ENYEDI GY. 1981). Az is gyakran ismétlödik, hogy a gazdasági-társadalmi fejlödés területi vetületéröl beszélnek, hogy az összekapcsolódás erősségét így is hangsúlyozzák. A későbbiekben látható lesz, hogy lényegében magam is ezen a véleményen vagyok, mégis úgy vélem, hogy a függőség kinyilatkoztatása, a 
területi jelenségek, összefüggések vetületként való értelmezése önmagában nem elegendő. Egyrészt azért, mert kézenfekvő, hogy a függés mértéke időben változó, másrészt azért, mert itt nyilvánvalóan vannak minóségi változások is. De nem kielégítő ezen felfogás azért sem, mert a térbeli eloszlás, struktúra ereje, visszahatása ma már sokoldalúan - ha nem is mindig kvarıtifikált formában - bizonyított. Ahhoz tehát, hogy ołyan magyarázattal rendelkezzünk, amely válaszokat nyújt a tudomány és gyakorlat oldaláról megfogalmazódó kérdésekre, a két nézőpont (külső függés, belsỏ hatás) ötvözésére van szükség.

Felismerték, sokan le is írták már azt, hogy a gazdasági fejlődési szakaszokhoz "megfelelö"(?) területi fejlödési szakaszok tartoznak. Automatikus összekapcsolódásról, tükörképről azonban köztudottan nem lehet szó, mivel a területi struktúra, a településrendszer változása időbeli késéssel követi a gazdasági változásokat. Ebból az is körvonalazódik, hogy ellentmondások is keletkezhetnek abból, ha adott idópontban a területi struktúra valamiben;, illetve valamilyen mértékben nem felel meg a társadalom vagy a gazdaság követelményeinek.

A külső függés és a belső folyamatok közötti viszony kissé mélyebb feltárása minden bizonnyal hozzájárul a területi folyamatok jobb megértéséhez és ezáltal a befolyásolás esélyeinek javításához. E kérdésekkel a hazai kutatók az elmúlt másfél-két évtizedben alig foglalkoztak, ezért manapság, amikor a fejlödés feltételeiben, az értékrendekben és célokban jelentős változások tanưi vagyunk, a hiányok még élesebben mutatkoznak meg.

A hazai területi elméleti kutatások háttérbe szorulása, másfelöl az igények, a kérdések egyre erőteljesebb megfogalmazódása, valamint az általában jellemző „nyitottságunk" vezet oda, hogy az elméleti hiányokat szinte megengedhetetlenül magas importtal pótoljuk. Megszaporodott az ołyan tanulmányok száma, amelyek szolgai módon követik, másolják a nyugat-európai országokban keletkező elméleti jellegü munkákat. Tetézi a gondot az is, hogy ezek közül sem a legmélyebbeket, hanem a „legkézenfekvőbbeket" hozzuk be (például az urbanizáció szakaszai), szinte figyelmen kivül hagyva a politikai, társadalmi, közgazdasági stb. környezet alapvető különbözóségeit. A nemzetközi tapasztalatok tanulmányozásának és felhasználásának szükségességét természetesen nem vitatom, hanem az egyoldalúságot és föleg a túl távolról merítést kifogásolom. Úgy gondolom, hogy a közép-keleteurópai tapasztalatokra kellene nagyobb figyelmet fordítani a hazai jelenségek mély elemzése és elméleti általánosítása mellett.

A nemzetközi tapasztalatok elemzését sokan azért sürgetik, mert úgy vélik, hogy ha ezt elég jól végezzük, akkor elkerülhetjük azon gondokat, amelyek egyes országokban megfigyelhetők, például a nagyvárosi zsúfoltságot, a faluról való elvándorlást stb. Tanulni persze kell, de csodákat várni nem szabad. Ahogyan gazdaság- és társadalomfejlódési gondjaink megoldására sem találhatunk külföldról egy az egyben alkalmazható sémát, akkor azt sem képzelhetjük józan ésszel, hogy a területi fejlóc'ús ugyancsak nagyon bonyolult, az adottságoktól annyira függô témakörében kész receptre akadhatunk Nyugaton!

MARX: „...Az egyik nemzet tanulhat és tanuljon a másiktól. Egy társadalom, még ha nyomára jött is mozgása természeti törekvésének - ... - természetes fejlödésị 
fázisokat sem át nem ugorhat, sem rendeletileg el nem tüntethet. De megröviditheti és enyhítheti a szülési fájdalmakat." (Idézet HERMANN 1983. alapján.)

A területi fejlődés átfogó elmélete ugyan ma sem áll rendelkezésre, ismertek azonban bizonyos általánositások, amelyek legalábbis hipotézis erejüek. Közülük legismertebbek a haranggörbék. A lényegi kérdéseket kutatva ALONSO (1980) is eljutott e görbékhez, azonban nem elégedett meg egyenkénti elemzésükkel, hanem kereste a közöttük levó összefüggéseket, és megfogalmazta kételyeit is. Figyelmét - nagyon indokoltan - a görbék jobb oldali lefutására, azaz a jelenlegi, illetve jövőbeli alakulására koncentrálja és sürgeti, hogy a kutatások foglalkozzanak e kérdésekkel.

Azt óhajtja tehát elösegiteni, hogyha a görbék verifikálhatók, akkor azok alapján vonjanak le következtetéseket a prognózisok, a befolyásolás számára. A követelmény racionális; alapvető kérdés azonban, hogy az igazi görbék csak harang alakúak-e, avagy folytatódnak...? E kérdésre még visszatérünk.

Más felfogás szerint (BARANOV, 1983) négy univerzális és egymással szoros kapcsolatban álló folyamat létezik: technikai haladás, urbanizáció, társadalmasítás (a termelési és fogyasztási eszközök köztulajdonának növekedése), demográfiai fejlödés.

CZAMANSKI (1976) az elméleti hiányosságokat emlitve arra mutat rá, hogy például a különböző természeti erőforrások, vagy a környezet minőségi tényezőinek a területi fejlődés szemszögéből való figyelembe vétele nem megoldott. Egyet kell értenünk a szerző azon megállapitásával is, hogy a korábbiakhoz képest sokoldalúbb elemzést és magyarázatot igényel a települések kialakulása: pl. azon aspektusból, hogy a viszonylag új települések is túlnyomórészt régiek helyén jönnek létre; ma már az is egyre nyilvánvalóbb, hogy a központi hely elmélet és a növekedési pólus elmélet megújításra szorul. ( $A z$ elöző azért - véleményem szerint -, mert a településrendszer strukturális átalakulása miatt a "központiság” nem értelmezhetö úgy, mint az egyedi településfejlödés szakaszában, a második pedig azért, mert a mai agglomerációk korábban vélt, vagy részben kimutatott gazdasági elönyei az ipari és telekommunikációs fejlödés következtében megszünőben vannak.)

A területi fejlődési elmélet gyengeségei mellett a területi elemzések eszközei jelentősen gazdagodtak - hangsúlyozza CZAMANSKI (1976), majd mintegy összegzésként a következóket írja: „A tudományos fejlődés jövőbeli menetét megjósolni nagyon kockázatos vállalkozás. Van azonban egy kézenfekvó terület, amelyben további kutatásra van szükség, és ez a térbeli eloszlások megfigyelt, de meg nem magyarázott szabályosságainak figyelmes vizsgálata."

\section{A területi fejlödés tényezöi}

A területi fejlödés tartalma és lényegi jellemzői azon tényezőkön keresztül ragadhatók meg, amelyeknek tartós hatásai kimutathatók. Érthető tehát, hogy a területi fejlödés tényezóinek megismerésére a külföldi és hazai szerzők nagy figyelmet fordí. tanak. Közhelynek számít annak hangsúlyozása, hogy a területi fejlödés legföbb sajátossága, megismerésének és befolyásolásának elsőrendú korlátja alkotó tényezőinek sokfélesége.

A kutatások többsége négy-öt tényezóit különböztet meg: gazdaságit, de- 


\section{LACKÓ LÁSZLÓ: A TERÜLETI FEJLŐDÉS EGYSÉGES ÉRTELMEZÉSE 70 - Tér és Társadalom 1. évf. 1987/1 67-75 pp.}

mográfiait, természetit, társadalmit és müszakit. Sorrendjük és a kifejtésben képviselt súlyuk attól (is) függ, hogy közgazdasági, földrajzi, múszaki stb. irányú vizsgálatról van-e szó. Söt, az alapvető felfogás még a szelekcióban is érvényesül.

Példaként tekintsük át elsőnek egy széles körü nemzetközi elemzés eredményeit (KORCELLI 1981). A táblázatból kitünik, hogy a tényezők között gazdasági, demográfiai, társadalmi, erőforrás-környezeti és politikai döntéshozói témacsoport szerepel. (1. táblázat)

1. tablazat

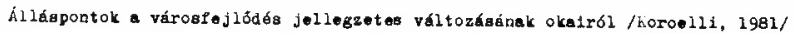

\begin{tabular}{|c|c|c|c|c|c|}
\hline $\begin{array}{l}\text { Tényezörk } \\
\text { fokok/ }\end{array}$ & $\begin{array}{l}\text { Leven, Cb. } \\
\text { /Francleorazág/ }\end{array}$ & $\begin{array}{l}\text { Illeris, } \\
\text { /Dania/ }\end{array}$ & Bourne, ${ }^{6 .}$ & $O E C D$ & ENS $Z$ EGB \\
\hline Uazdentgi & $\begin{array}{l}\text { A sorozatnegyság } \\
\text { és oz agglomerálo- } \\
\text { dég gazdagág1 eló- } \\
\text { nyeinek cabkeno } \\
\text { gzerepe. }\end{array}$ & 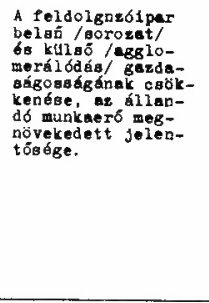 & 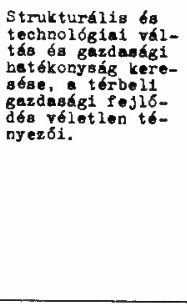 & 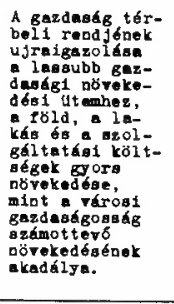 & 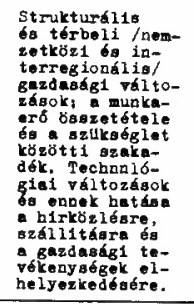 \\
\hline Demográfial & 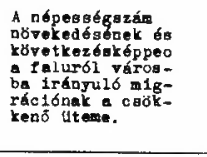 & $\begin{array}{l}\text { Változó korgtruk- } \\
\text { tura és canlád- } \\
\text { óazetótel. }\end{array}$ & & $\begin{array}{l}\text { A népeság vál. } \\
\text { tozólonsidae } \\
\text { ég elóregedése } \\
\text { városon belul. }\end{array}$ & 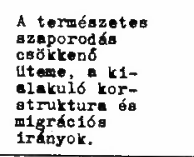 \\
\hline Társedela1 & 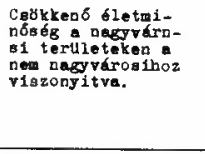 & $\begin{array}{l}\text { A nasy speciali- } \\
\text { zalt intémények } \\
\text { caokkeob azerepe. }\end{array}$ & 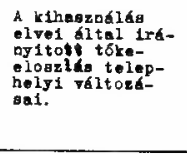 & 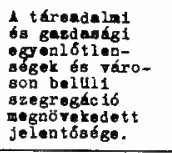 & 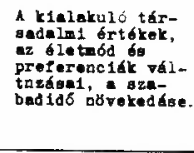 \\
\hline $\begin{array}{l}\text { Eroforráo- } \\
\text { kórnyezoti }\end{array}$ & & $\begin{array}{l}\text { A pagyvárog1 zbr- } \\
\text { ayezet leromlása. }\end{array}$ & 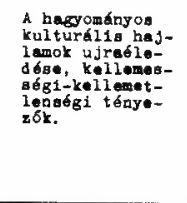 & 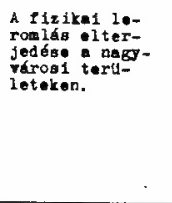 & 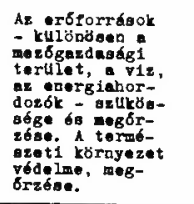 \\
\hline $\begin{array}{l}\text { Politikai } \\
\text { döntóannzó }\end{array}$ & 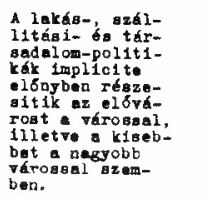 & 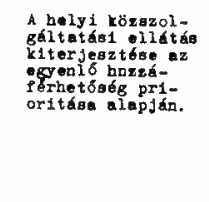 & 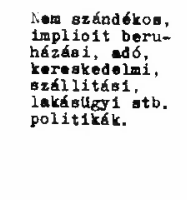 & 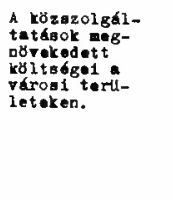 & 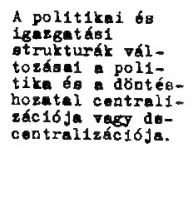 \\
\hline
\end{tabular}

BARTKE többnyire társadalmi-gazdasági, természeti és müszaki tényezóket különböztet meg; legújabb munkájában (BARTKE I. 1985) a természeti tényezök nyitják a sort, majd a társadalmi-gazdasági feltételek következnek.

Véleményem szerint a területi fejlődés tényezói a következők: 1. természeti, 2. társadalmi, 3. gazdasági, 4. müszaki, 5. a már kialakult területi struktúra, 6. irányítá- 
si. Az elemzésekból kitūnt (LACKÓ L. 1985), hogy a tényezők nem egyenszilárdságúak, vannak közöttük merevebbek, nehezebben változóak: természeti, müszaki, kialaku/t struktúra, és vannak képlékenyebbek, változékonyabbak: társadalmi, gazdasági, irányitási.

A csoportositás természetesen viszonylagos; találhatók részelemek, amelyek a másik kategóriába kivánkoznak, az elsődleges kategorizálás azonban tapasztalati úton is bizonyítható. $A z$ is elfogadható, hogy a tényezők hatásainak erősségében változások, ingadozások figyelhetök meg.

Véleményem tehát $a z$, hogy a természeti faktor hatása némiképp, a társadalmié eróteljesen fokozódik, a gazdasági viszont veszít súlyából. És másfelől az irányítás hatása számottevő̉en, a struktúráé csekélyebb mértékben erősödik, a múszaki tényező pedig lényegében a korábbival egyező szintet mutat. Végül említést érdemel az is, hogy vizsgálataim szerint az egyes tényezők viszonylagos fontossága eltérö a területi fejlődés értelmezési szintjein. (1. ábra).

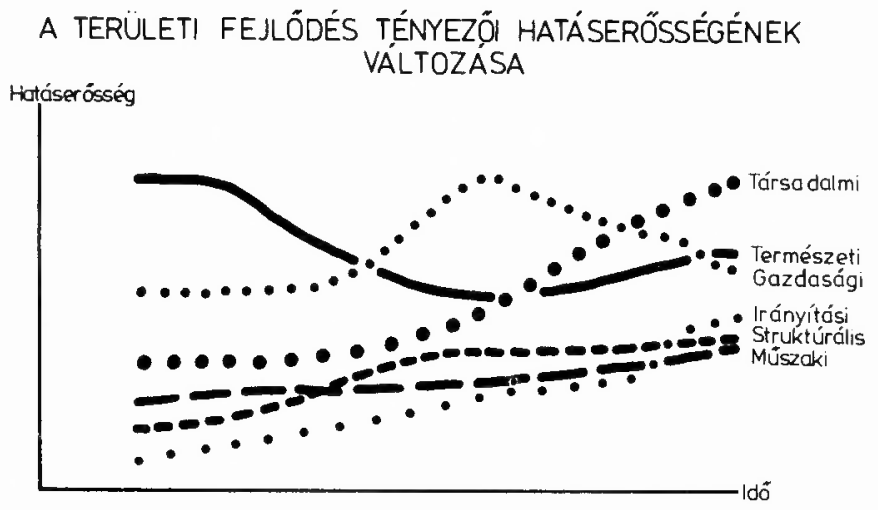

1. ábra

\section{Területileg egyenlötlen fejlödés}

A területi fejlődésnek meghatározó sajátossága, hogy térben egyenlötlenül megy végbe. Ennek oka az, hogy a fejlödési tényezók térbeli eloszlása egyenlötlen.

Az egyenlötlen területi fejlődési koncepciót a nyugati országokban általában elutasitják, föként olyan alapon, hogy az végül is nem más, mint a tőkés társadalmi rend elleni támadás. RICHARDSON (1984) például az egyenlótlen területi fejlödés koncepcióját úgy állítja be, mintha annak lényegi elemei a következők lennének: „Elöször antagonizmus áll fenn a város és a vidék között. A falusi szektort kizsákmányolják úgy, hogy feleslegeit a városi kapitalisták javára használják... Másodszor, a termelés térbeli koncentrációja nem a piaci orientáció (azaz a szállítási költségek minimalizálásának) vagy a nyersanyagok egyenlötlen térbeli eloszlásának eredménye, hanem a töke nagy termelési egységekbe - különösen a feldolgozóiparba - való koncentrációjának 
következménye. Harmadszor, kapcsolódva az elóző ponthoz, a tőke térbeli behatolása nagyon egyenlótlen. Mivel a tőkés döntéseket a magánprofit hajszolása jobban motiválja, mint a társadalmi haszon, ezért az országnak nagy területei keletkezhetnek, ameIyek a beruházás szempontjából krónikusan hátrányos helyzetben vannak (a stagnáló helyek állandó tartaléka)... Negyedszer, a tóke nagyon mobil, és ez a mobilitás a kizsákmányoláshoz sok lehetôséget nyújt ... Ötödször, a területi politika regionális eleme teljesen mellékes, és annak ködösítésére szolgál, hogy nagy támogatást lehessen nyújtani az ipari tőkének a profitnyomás túlélése érdekében. Összegezve, ez egyenlőtlenséget okoz olyannyira, hogy szükségszerú mellékterméke a személyes egyenlötlenségeknek, és a tökefelhalmozás alapja."

A fentiekkel ellentétben - egyetértve BARTKÉ-val - úgy vélem, hogy az egvenlótlen területi fejlődés elméletéböl logikusan levezethetők és magyarázhatók a területi változások és képződmények.

$\mathrm{Az}$ egyenlőtlen területi fejlődés elemi megnyilvánulási formája a település, amelyben a természeti, társadalmi, gazdasági és múszaki tényezők sajátos térbeli koncentrációja jelenik meg. Egyetértek tehát BARTKÉ-val abban is, hogy a települések fejlódésének sajátosságait csak a területi fejlödés általános törvényszerüségei alapján lehet megérteni, magyarázni. Az adottságok, tevékenységek, funkciók térbeli sürüsödései, ritkulásai hozzák létre és tartják életben a településeket. A különböző tényezők előfordulása, hatásainak változása kimutatható mind az egyes települések, mind a településrendszer(ek) tekintetében. Másfelöl közelitve, a települések fontos mérföldkövei a társadalmi munkamegosztásnak: azt mondjuk például, hogy „A kézmüvesség és a földmüvelés különválásával megkezdődött a város és falu elkülönülése, amely folyamat óriási szerepet töltött be a társadaimi munkamegosztás elmélyülésében." (A Politikai gazdaságtan kisszótára, 1981, p. 394.) Ezzel összefüggésben felmerül a kérdés, hogy ha "óriási szerepet" játszik a két alapvető településforma megjelenése és élete a társadalmigazdasági folyamatokban, akkor ez miért nem tükröződik például a politikai gazdaságtanban?

A területi munkamegosztást többnyire térségenként értelmezik, ami azonban kiegészitésre szorul, mivel a területi munkamegosztás települések közötti kapcsolatokban valósul meg, és az sem hagyható figyelmen kivül, hogy a település a munkamegosztás „terméke". Ez a lényegi összefüggés is alátámasztja a területi és településfejlödés egységes felfogásának szükségességét.

A társadalmi és a területi munkamegosztás, valamint a településfejlödés átfogó szakaszai között kézenfekvő összekapcsolódás mutatkozik. Az első nagy társadalmi munkamegosztás nyomán válnak jól láthatóvá - a területileg egyenlőtlen fejlődés első eredményeként - a települések. A második nagy társadalmi munkamegosztással veszi kezdetét a város és a falu elkülönülése, ami a harmadik társdalmi munkamegosztás kibontakozásával elmélyül.

A szellemi és fizikai munka szétválasztása és ennek térbeli következményei, valamint a gépi termelés elterjedése, a munka termelékenységének növekedése, a müszaki haladás eredményei és az infrastruktúra kiépülése révén folyamatosan teremtődnek meg a területi-települési specializálódás feltételei. A rabszolgatartó társadalmak „általában városai” után már a feudalizmus korában bizonyos specializáció jelentkezik (egvetemi város, vásárváros, kereskedóváros, kikötőváros stb.). Ez a folyamat hatalmas 
méretǔvé válik a tőkés fejlődés korai és középső szakaszában. A század első évtizedei a funkciók sokrétübbé, gazdagabbá válása jegyében teltek el, a legutóbbi időben pedig (talán főként a számítástechnikai forradalommal összefüggésben) újra a specializálódás (de kisméretü egységekben) jelei mutatkoznak.

A vázoltakból az is következik, hogy az ősi, alapvetően lakófunkciót betöltő település későbbi létét és további fejlődését a gazdasági tevékenységek - földmüvelés, kézmúvesség, kereskedelem, ipar - határozták meg. A történelmi tapasztalatok tehát ezen szemszögből is igazolják, hogy az egyenlötlen területi fejlödés eredményezte települések fejlődésében a gazdasági bázis mennyire jelentós. Ez nem mond ellene annak, hogy a területi munkamegosztás és a települések létrejöttében nagy szerepet játszanak a természeti adottságok és eröforrások.

Másfelöl, a település létét, változásait a forma és tartalom olyan dialektikus egységeként kell értelmezni, amelyben a tartalmat a társadalom, a gazdaság, a termelöerők, a társadalmi és természeti viszonyok összessége jelenti, a formát pedig a társadalom, a gazdaság, az emberek léte és tevékenysége során létrejött építmények és környezet együttese alkotja. A forma és tartalom egysége és ellentmondásai nyilvánulnak meg a települések létrejöttében, a forma viszonylagos állandósága miatt bekövetkező feszültségekben. A változó társadalom és gazdaság igényeit a régi forma egyre kevésbé képes kielégíteni, ezért bizonyos határ után konfliktusok, válságok jönnek létre. Az ezek megszüntetését szolgáló beavatkozások új vagy módosult formát hoznak létre. A kialakuló egyensúly azonban (itt is) csak viszonylagos és időszakos lehet, mivel a tartalom változása folyamatos.

A településfejlödés nem más, mint a területi fejlődés megjelenési formája, mivel a település sem egyéb, mint a területi fejlődés egyik kézzelfogható eredménye, képződménye, jól megfigyelhető objektuma. A területi fejlódés természetesen nyomon követhető különböző szinteken. Kartográfiai analógiával élve a részletek a nagy méretarányú térképet - a települést, annak részeit - az összefüggések, átfogó folyamatok a közép- és kisméretarányú térképet - a térségeket, összefüggỏ területeket jellemzik. A tanulmányozandó téma jellege, részletessége szabja meg, hogy mire van szükség. És miként a térképek sem csak méretarányuk, hanem elsősorban tartalmuk szerint különböznek, ugyanúgy a területi fejlödés aspektusai is tanulmányozandók és befolyásolandók települési vagy területi szinteken. Attól, hogy egyik vagy másik tartalmi elem van túlsúlyban, vagy valamelyik hiányzik, a térkép - térkép marad. Annak alapján, hogy fốként a térbeli folyamatok gazdasági, müszaki összefüggéseit vizsgáljuk, nem változik a lényeg, az, hogy a területi fejlödést elemezzük.

Mindezekből következik, hogy a külföldi és a hazai szakirodalom többségével ellentétben nem tartom megalapozottnak azt sem, hogy az urbanizációt mint valamiIyen sajátos jelenséget, a területi fejlődéstől elkülönítve értelmezzék, elemezzék, és úgy állitsák be, mint egy mindent átható, objektív folyamatot. Lényegében ugyanis az urbanizáció fogalma alá a területi fejlódés egyes megnyilvánulásait (a népesség, az ipar, a szellemi tevékenységek városokba való tömörülését, a civilizáltabb életkörülmények terjedését stb.) vonják. Olyan túlzás is előfordul, hogy az urbanizációt a társadalmi fejlödéssel azonosítják.

$A z$ urbanizáció értelmezésével, mérésével kapcsolatos megjegyzésekból már következik, hogy sok külföldi és hazai szerzőtől el téröen nem vagyok híve az európai urbanizáció négy szakaszát kimutató „elméletnek”. (2. ábra) 


\section{A NÉGYSZAKASZOS URBANIZÁCIÓ SÉMÁJA}

(Klaassen, Bourdrez, Volmuller, 1981 alapján)

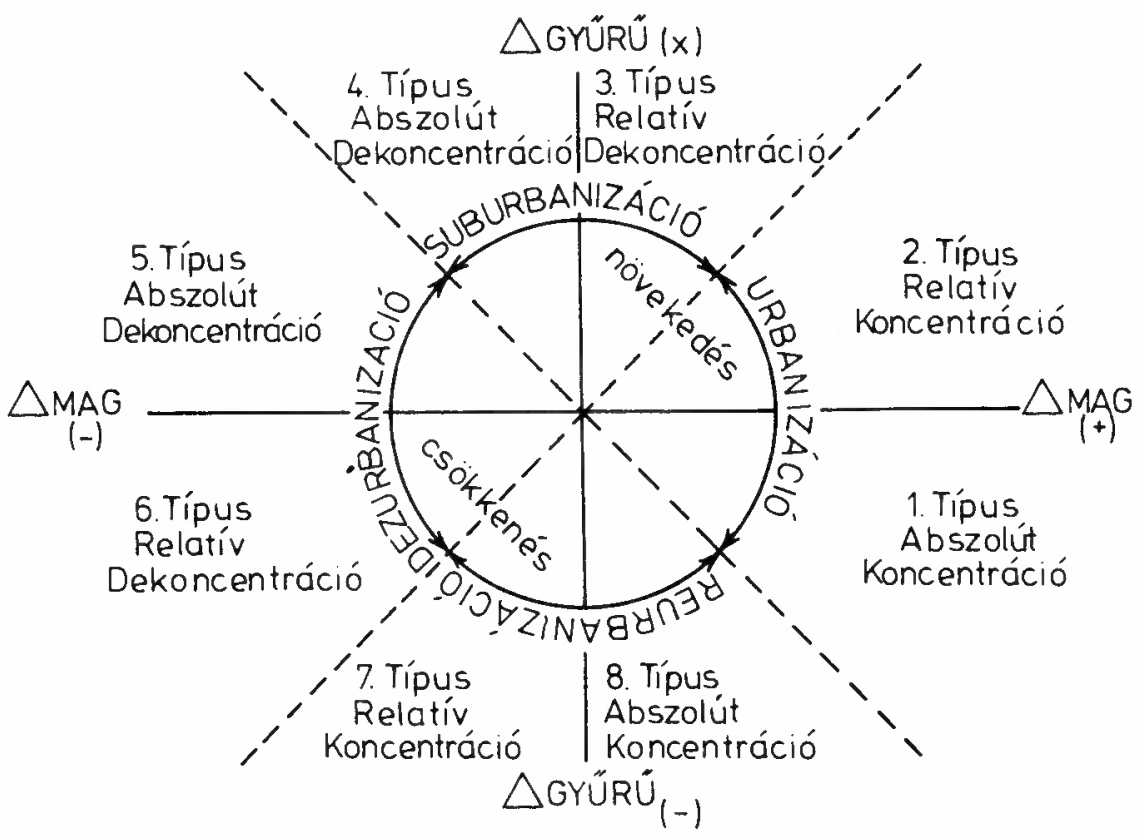

2. ábra

Ellenvéleményem tulajdonképpen három forrásból táplálkozik:

1. Az általánositás alapjául szolgáló eredeti vizsgálat a holland agglomerációs fejlődést elemezte. Hollandia történelmi fejlődése, gazdasági potenciálja, népsürüsége, településrendszerének összetétele oly nagy mértékben elüt Európa egyéb részeitól, hogy a párhuzamok, hasonlóságok keresése eleve eróltetett. Az időbeli eltéréssel egyéb országokban jelentkező hasonlóságok mozgató rugói mások, mint Hollandiában, illetve alapvetően a társadalmi-gazdasági és a területi fejlödés - aminek a nagyvárosi fejlödés egy része - következményei.

2. A másik - még fontosabb - szempont, ami miatt a négyszakaszos urbanizációs okfejtés nem általánositható: nem nyưjt magyarázatot a településrendszer egészének, illetve nem agglomerálódott részeinek fejlödésére vonatkozóan. Az urbanizảció pedig semmiképpen sem értelmezhető és szükithető csupán a nagyvárosi területekre.

3. Nemcsak a séma ad olyan képet, hanem a szöveges kifejtés is úgy hangzik, hogy az "utolsó szakasz" a reurbanizáció. Ez azt a benyomást kelti, mintha az urbanizációt zárt körben mozogva lehetne, illetve kellene elképzelni, aminek volt egy kezdete (koncentráció) és van egy vége.

Ez már oly mér tékben túlzott leegyszerüsítés, hogy elfogadhatatlanságát részletesebben talán nem szükséges indokolni. Elég például utalni arra, hogy az újjáéledő belvárosok aligha vethetök össze régi sajăt magukkal, sem funkcionális, sem formai, épitészeti tekintetben. Az a benyomásom, hogy a holland nagyvărọsok tér ségére elvég. 
zett elemzést olyan módon „általánosították”, ami távol állt a szerzők eredeti törekvéseitől. A félreértések azonban ma már elég nehezen helyesbíthetök.

A négyszakaszos urbanizáció kisértete ugyanis járja Európát ..., aminek oka az, hogy a népesség számának, sürüségének kiszámításához az adatok mindenütt rendelkezésre állnak, tehát sokféle számítás végezhető azon konvenció alapján, amely az urbanizációt a városokban élök számával méri. Másfelől azonban megjegyzem azt is, hogy a négyszakaszos urbanizációs „elmélet“ hatása kedvező volt Magyarországon, mert ráirányitotta a figyelmet a nagyvárosi fejlödésben statisztikai adatokkal is kimutatható szakaszosságra - ha tetszik: a ciklusokra.

\section{IV. Összefoglalás}

A település, mint a természeti, társadalmi, gazdasági és müszaki tényezök térbeli koncentrációja, úgyszintén az egyenlötlen területi fejlödés elemi megnyilvánulási formája. Másfelől a település a társadalmi munkamegosztás terméke, és végül is a területi munkamegosztás települések közötti kapcsolatokban valósul meg. A területi fejlödés tényezői - bármely nagyobb vagy kisebb területen - együtt alkotják a területi fejlödést magát, tehát a területi vagy településfejlődés nem különíthető el, mivel csak ugyanazon jelenség más és más szintjét képviselik.

IRODALOM

ALONSO, W.: 1980. Five Bell Shapes in Development Papers, Regional Science Association Vol. XLV.pp. 5-16.

BARANOV, A. V.: 1983. Sztagyii evolucii szocialisztyicseszkogo goroda. Regionalnije szisztyemi 2. pp. 100-105.

BARTKE 1.: (szerk.) 1985.a. A területfejlesztési politika Magyarországon. Akadémiai Kiadó Bp.

BARTKE I.: 1985.b. A területi egységek („,körzetek") szerepe a területi tervezésben. OT Tervgazdasági In tézet, Bp.

CZAMANSKI S.: 1976. The Evolving Epistemology of Regional Science. Papers of the RSA Vol. XXXVII.

ENYEDI GY.: 1981. A területfejlesztési politika néhány új elemérobl. Területi Statisztika 2.

HERMANN 1.: 1983. „Rólunk szól a mese..." Marx halálának 100. évfordulójára. Magyar Tudo. mány 5. pp. 329--334.

KLAASSEN, LEO H.-BOURDREZ, J. A.-VOLMULLER, J.: 1981. Transport and Reurbanisation. Aldershot, England.

KORCELLI, P.: 1981. Migration and Urban Change. IIASA WP

KÓRÓDI J.: 1968. Az ipar telepítése. (Akadémiai doktori értekezés) Bp., KÉZIRAT.

KÖSZEGI L.: 1964. A területi tervezés föbb elvi és módszertani kérdései. Közgazdasági és Jogi Könyvkiadó Bp.

LACKÓ L.: 1985. A területi fejlødés befolyásolásának lehetőségei és korlátai. Akadémiai doktori értekezés. Bp., KÉZIRAT.

MARKOS GY.: 1956. A területi tervezés alapelvei és feladatai. Természet és társadalom. 6. sz. pp. $341-344$.

RICHARDSON, H. W.: 1984.a. Approaches to Regional Development Theory in Western-Market Economies. In: Ed. DEMKO G.: Regional Development Problems and Policies in Eastern and Western Europe Croom Helm, London pp. 4-33. 